Spring 2017

\title{
The Rights of Future Persons and the Ontology of Time
}

Aaron M. Griffith

College of William and Mary, amgriffith@wm.edu

Follow this and additional works at: https://scholarworks.wm.edu/aspubs

\section{Recommended Citation}

Griffith, Aaron M., The Rights of Future Persons and the Ontology of Time (2017). JOURNAL OF SOCIAL PHILOSOPHY, 48(1).

$10.1111 /$ josp. 12180

This Article is brought to you for free and open access by the Arts and Sciences at W\&M ScholarWorks. It has been accepted for inclusion in Arts \& Sciences Articles by an authorized administrator of W\&M ScholarWorks. For more information, please contact scholarworks@wm.edu. 


\title{
The Rights of Future Persons and the Ontology of Time
}

\author{
Aaron M. Griffith
}

\section{Introduction}

Many are committed to the idea that the present generation has obligations to future generations, for example, obligations to preserve the environment and certain natural resources for those generations. However, some philosophers want to explain why we have these obligations in terms of correlative rights that future persons have against persons in the present. ${ }^{1}$ Attributing such rights to future persons is controversial, for there seem to be compelling arguments against the position. According to the "nonexistence" argument, future persons cannot have rights (and so should not be attributed rights) because they do not exist. According to the "no-satisfaction" argument, future persons cannot have a right to resources that do not exist at the time of their existence because such a right could not, in principle, be satisfied. In this paper, I will argue that an eternalist ontology of time provides the resources for satisfactorily responding to both the nonexistence and the no-satisfaction arguments. ${ }^{2}$

Eternalism is a prominent view of time that is defended by a number of metaphysicians. ${ }^{3}$ The eternalist understands the world in time to be a "block universe," that is, a four-dimensional space-time manifold containing times that are related to each other by the tenseless relations being earlier than and being later than. Eternalists think that time is similar to space in a crucial respect: being temporally remote from this moment makes no more difference to the ontological status of an object than being spatially remote from this location does for the ontological status of an object. Consequently, past, present, and future objects all exist and are equally real on eternalism. To say that past and future objects exist, is not to say that they exist presently. Instead, the eternalist holds that past and future objects exist tenselessly, which is to say that they exist at the times they do (either earlier than or later than this one) in exactly the same manner that objects existing at this moment do (cf. Fiocco 2013, 216).

Eternalists claim a number of advantages for their view over competing ontologies of time like presentism, the view that only present objects exist,${ }^{4}$ and growing block theory, on which past and present, but not future, objects exist. ${ }^{5}$ Unlike its competitors, eternalism is said to be able to account for (i) crosstemporal relations, (ii) the reference of terms (apparently) denoting nonpresent objects, and (iii) plausible truthmakers for past and future contingent truths. Some eternalists argue that it is the only ontology of time that is consistent with 
the special theory of relativity. ${ }^{6}$ Of course, whether eternalism enjoys these advantages exclusively is disputed. ${ }^{7}$ These debates need not concern us, however, for I intend to argue here that if eternalism is true, then two key arguments against attributing rights to future persons can be convincingly rebutted. ${ }^{8}$ In the conclusion of the paper, I will consider some of the ramifications the truth of eternalism would have for debates about intergenerational ethics.

The two arguments that are the focus of this paper are not, I should note, the only arguments against grounding present persons' obligations in future persons' rights. The much discussed "nonidentity" problem developed by Thomas Schwartz (1978), Robert Merrihew Adams (1979), Gregory Kavka (1981), and, most forcefully, by Derek Parfit $(1987,351 \mathrm{ff}$.) poses a challenge for any view on which we would have obligations to future persons whose existence and identity are contingent upon our decisions, but whose lives would be unavoidably flawed in some way. Although a full defense of the view that future persons have rights will have to answer the nonidentity problem, I will not be addressing the problem here. The present effort makes a contribution by removing two other basic roadblocks to attributing rights to future persons, which pose a challenge to a theory of intergenerational rights, whether or not the nonidentity problem proves intractable. ${ }^{9}$ I turn now to the nonexistence argument and the eternalist response to it.

\section{The Nonexistence Argument}

The nonexistence argument is the most common argument given against attributing rights to future persons. Some authors take the argument to be the central and decisive blow to views attributing rights to future persons. ${ }^{10}$ The crux of the argument is that future persons cannot have rights (and so should not be attributed rights) because they do not exist. Here is Richard De George's formulation of the argument:

Future generations by definition do not now exist. They cannot now, therefore, be the present bearer or subject of anything, including rights. Hence they cannot be said to have rights in the same sense that presently existing entities can be said to have them. This follows from the briefest analysis of the present tense form of the verb "to have." $(1981,159)$

Echoing De George, Wilfred Beckerman and Joanna Pasek offer a similar argument:

[Future persons] do not exist ... by definition, future persons have not yet arrived. $(2001,19)$

Thus the general proposition that future generations cannot have anything, including rights follows from the meaning of the present tense of the verb "to have." Unborn people simply cannot have anything. $(2001,16)^{11}$

Other variants of the argument deny rights to future persons on the grounds that such persons have a diminished ontological status, being merely potential, merely possible, and so on. 
According to Ruth Macklin,

\begin{abstract}
The chief argument in support of the position that future generations cannot correctly be said to have rights rests on the premise that the ascription of rights is properly to be made to actual persons-not possible persons. Since future generations can only be viewed as consisting of possible people, for any vantage point at which the description "future people" is applicable, it would follow from the aforementioned premise that rights cannot properly be ascribed to future generations ... Even if we believe that there will be such actual persons in the future, their rights cannot be said to exist until they (the persons) exist. $(1981,151)$
\end{abstract}

The formal argument implicit in these quotes seems to be as follows:

(i) Future persons do not exist (are not actual).

(ii) If $x$ does not exist (is not actual), then $x$ cannot bear rights.

(iii) Therefore, future persons cannot bear rights.

The argument begins with a claim about the ontological status of future persons, namely that they lack existence (or actuality). Premise (ii) states that existing (or being actual) is a necessary condition for having rights. It assumes (a) that having a right involves or entails having certain properties or standing in certain relations and (b) the truth of the following principle: necessarily, an object $x$ has property $\mathrm{F}$ or stands in relation $\mathrm{R}$ to something only if $x$ exists. ${ }^{12}$ Given (i), (ii), and assumptions (a) and (b), it follows that future persons cannot have rights. If they cannot have rights, then they do not have rights. Hence, it is inappropriate to attribute rights to future persons.

\title{
2.1. Eternalism and the Nonexistence Argument
}

Eternalism, we said, is the view that past, present, and future objects and times exist and are equally real. Past and future objects tenselessly exist at the times at which they do. Let "EXISTS" denote tenseless existence and "HAVING" denote the tenseless having of a property, that is, an object's having a property at the time at which it EXISTS. Given this framework, it is straightforward how the eternalist will respond to the nonexistence argument. She will deny premise (i), that is, deny that future persons have the demoted ontological status her interlocutor says they do. For her, future persons EXIST at times later than this one and are no less real, existent, or actual for this. Independently of a metaphysical assumption that the eternalist rejects, viz., that future persons do not exist, an "analysis of the present tense form of the verb "to have" (De George 1981, 159) does nothing to show that future persons do not have rights. Such an analysis is irrelevant to the eternalist who holds that future persons EXIST at times later than this one and HAVE rights at those times.

Proponents of the nonexistence argument endorse (i) because they tend to assume that for a person to exist is for her to exist presently. On the basis of this 
assumption, they reason that for a person to have a right is for her to have that right presently. Of course, the eternalist agrees that future persons do not exist presently (for it is incoherent to say "future persons now exist," if that means that a person who only EXISTS at times later than this one, also EXISTS at this time). But she does think they EXIST and can affirm that EXISTENCE, but not present existence, is a necessary condition for having a right. Because our eternalist thinks that future persons EXIST at times later than this one and HAVE rights at those times, her defense of the attribution of rights to future persons does not depend on the implausible claim that future persons now exist and now have rights.

Moreover, the eternalist might hold that future persons HAVE rights at the times at which they EXIST and some of those rights entail correlative duties for people in the present. That is, $\mathrm{S}_{2}$ may have a right $\mathrm{R}$ at $t_{2}$ and $\mathrm{R}$ is correlative with a duty $\mathrm{D}$ had by $\mathrm{S}_{1}$ at an earlier time $t_{1}$. This gives us an eternalist response to the following argument from Beckerman and Pasek:

\footnotetext{
Suppose somebody had made preparations to set off a bomb in, say, two hundred years' time, or buried some radioactive nuclear waste in an unsafe location. This would harm a lot of people who do not yet exist. But it would be wrong to say that their rights not to be harmed had been violated. For since they did not exist when the delayed-action bomb was planted they could not be said to have any rights. (2001, 17-18)
}

On eternalism, a person need not exist at the time an action is performed for that action to help constitute a violation of her rights. If a person EXISTS and is harmed by the exploding bomb at a later time $t_{2}$, we can say that the planting of the bomb at the earlier time $t_{1}$ helps constitute a violation of the rights of the person EXISTING at $t_{2}$.

Dennis Earl (2011) argues that future persons have no rights against present persons. In arguing this, he claims that eternalism cannot help us resolve the following inconsistent triad: (I) Future generations have rights; (II) Future generations do not exist; (III) In order for $\mathrm{X}$ to have rights $\mathrm{X}$ must exist. All of these claims, says Earl, are prima facie plausible, yet they are incompatible and so generate a paradox. Eternalists attempt to resolve the inconsistency by denying (II), for they think that future persons EXIST. However, Earl claims that resolving the inconsistency this way equivocates on the meaning of "exists" in (II), which he takes to mean "presently exists" $(2011,64)$. Technically speaking, the eternalist does not equivocate on the meaning of "exists." Eternalists and presentists can agree that there is a single meaning of the existential quantifier; what they disagree about is whether any nonpresent objects are the values of bound variables. Nevertheless, if we read "exists" as Earl suggests, that is, as "presently exists," then the eternalist will now affirm (II) and deny (III). For she thinks that one can have rights even if one EXISTS at a time other than this one; present existence is not necessary for having rights on eternalism. Earl's triad, then, only appears to be inconsistent if we assume that to exist presently is to 
exist simpliciter. This is a presentist assumption that the eternalist rejects. So Earl has not presented a compelling case to the eternalist for thinking that (I) rather than (II) (or (III)) is the culprit of the triad. ${ }^{13}$

\section{The No-Satisfaction Argument}

Defeating the nonexistence argument does not entail that future persons have rights against presently existing persons, even in the eternalist framework. Premise (ii) of the nonexistence argument is a necessary, but not sufficient, condition for someone's having a right. Depending upon the right in question, various other conditions may need to be satisfied. For example, the possession of certain legal rights requires a person to occupy some "office" or "position," such as being a citizen of certain country or being of a certain age, and so on. Some think a more general condition on having any right whatsoever is that it be logically possible to satisfy the right. That is,

Satisfaction: A person P has a right R only if it is logically possible to satisfy R for P. ${ }^{14}$

Satisfaction is a plausible condition on having a right. It does seem that no one can have a claim on or an entitlement to something it is logically impossible for her to have. A right that is logically impossible to satisfy would require the bearer of the correlative duty to do something logically impossible. But it is widely held that no one is obligated to do something that she cannot do. ${ }^{15}$ If that is right, then no one has a right that is logically impossible to satisfy. Satisfaction, moreover, can be used to generate another argument against attributing rights to future persons, one that poses a challenge to the eternalist. Even if future persons exist, they cannot correctly be attributed rights if those putative rights would be logically impossible to satisfy.

Versions of the no-satisfaction argument are found, again, in Beckerman and Pasek (2001) and De George (1981). The former argue that future persons cannot have a right to oil, gas, coal, or clean water if such resources do not exist by the time future persons come into existence $(2001,16)$. The reason they cannot have such a right is that once those resources go out of existence, it is not "in principle" possible to satisfy the (putative) right. They compare attributing rights to future persons to resources that do not exist at the time of their existence to attributing a right to a child, "Tommy," to a toy that was just destroyed by another child, "Billy." Tommy, they claim, may have a right to compensation from Billy, but because the toy no longer exists, we cannot say that he has a right to that very toy, since it is impossible to satisfy such a right for Tommy. Similarly, De George writes, "[a being] has a right only to the kind of treatment or to the goods available at the time of its conception. It cannot have a reasonable claim to what is not available" $(1981,160)$. His reason for thinking that no one has a right to what is not available at the time of her existence is, 
presumably, that such a right could not be satisfied. The formal no-satisfaction argument behind these remarks seems to be this:

(iv) A person $\mathrm{P}$ has a right $\mathrm{R}$ only if it is logically possible to satisfy $\mathrm{R}$ for $\mathrm{P}$.

(v) It is logically impossible to provide future persons with particular resources that have been used up by the time of their existence.

(vi) Therefore, no future person has a right to resources that have been used up by the time of her existence.

Premise (iv) is, obviously, Satisfaction. The notion of "satisfying a right" in (iv) should be understood broadly to include anything that would discharge the obligation correlative to the right, for example, by providing what the right gives its bearer a claim to or by the bearer waiving the right. (v) needs to be treated with some care. I take it that it is not to be read as "There is no possible world in which future persons enjoy certain resources that, in the actual world, have been used up by the time of their existence." Instead, it ought to be understood, as the argument's proponents seem to intend it, in light of the assumption that the past is fixed, that is, if an event $e$ has taken place, then it is true that $e$ has taken place and will remain true regardless of what events occur after $e$ has taken place. Hence, if the resources thought to be owed to future persons have been used up or wasted by the time of their existence, there is nothing that can be done at that time to satisfy their rights, since no one has any power to change what happened in the past. So understood, (v) implies that at the time of their existence, it is logically impossible to satisfy the rights future persons are alleged to have to certain resources. Together with (iv), (v) entails the conclusion, (vi).

If successful, the no-satisfaction argument would only show that future persons have no rights to particular resources. But one might think that future persons have rights against present persons, not to particular resources, but to the benefits those resources produce ${ }^{16}$ or to general conditions required for living and thriving, for example, having clean air and water, having consistent and reliable food sources, and so on. Such a concern could be accommodated, however, by amending (v) to refer to such benefits and conditions rather than particular resources. For our purposes, nothing turns on which version of the nosatisfaction argument we opt for; the eternalist response presented in the next section is equally as effective against both versions.

\subsection{Eternalism and the No-Satisfaction Argument}

Satisfaction, (iv), let us assume, is a necessary condition on having a right. But are proponents of the no-satisfaction argument correct in thinking that future persons cannot satisfy this condition with respect to present resources? In response to the argument, the eternalist should first insist that (v) be made more precise. The question "is it logically possible to satisfy R for P?" has no answer unless it is 
indexed to a time. It may be impossible at $t_{2}$ to prevent an event $e$ from taking place at an earlier time $t_{1}$, yet it might be possible at $t_{1}$ (or a time earlier than $t_{1}$ ) to prevent $e$ from taking place. To say that it is impossible at $t_{2}$ to prevent $e$ is, again, not to say that there is no possible world that includes $e$ in a history up to $t_{2}$. It is to say that at $t_{2}$, the past is closed, that nothing can be done at $t_{2}$ or later can make it the case that $e$ did not occur. However, at $t_{1}$, it is open whether event $e$ will take place or not, which is to say that it is unsettled or indeterminate at $t_{1}$ whether $e$ will take place at $t_{2} .{ }^{17}$ If this is correct, then determining whether a person $\mathrm{P}$ meets the condition on having right $\mathrm{R}$ expressed by (v) turns on what the appropriate time of evaluation is for the logical possibility of satisfying $\mathrm{R}$ for $\mathrm{P}$.

Proponents of the no-satisfaction argument tend to assume that rights and their correlative duties are always had at the same time. (This is likely due to the fact that most of those thinking about the moral status of future persons assume that only the present is real, which entails that there is only one time at which any rights and duties are had.) The eternalist should say that the time at which a right $\mathrm{R}$ is HAD need not be identical to the time at which R's correlative duty D is HAD. Thus, future persons can HAVE rights at the times at which they EXIST, while the duties correlative to those rights are HAD by persons EXISTING at earlier times. The reason we should "locate" rights and duties at the times at which their bearers exist is that those rights and duties depend for their existence and normative force on their bearers. ${ }^{18}$ If, for example, we said that person $\mathrm{P}$ is the bearer of right $\mathrm{R}$, but that $\mathrm{P}$ does not exist, there would seem to be no way to explain why $\mathrm{R}$ belongs to $\mathrm{P}$, that is, why $\mathrm{R}$ is $P$ 's right in particular. Moreover, if $\mathrm{P}$ does not exist, there would seem to be no way to explain why $\mathrm{R}$ would generate any obligation for another person(s). For if there is no one who is entitled to something or who has a claim to something, then it is difficult to explain how anyone would be obligated, in virtue of that right, to satisfy that right.

Once it is acknowledged that rights and their correlative duties can be located at different times, the eternalist can argue that proponents of the no-satisfaction argument are wrong to think that the appropriate time at which to evaluate whether it is possible to satisfy the rights of future persons is the time at which those persons exist. It is the earlier time at which D is HAD, and not the later time at which R is $\mathrm{HAD}$, that is the appropriate time at which to evaluate whether it is logically possible to satisfy $\mathrm{R}$ for its bearer. The reason for this is that the bearers of $\mathrm{D}$ are the ones obligated to satisfy the demands of R. No one, let us suppose, is obligated to do something that it is logically impossible for them to do, which is why the question of whether a person has a right to something is (partially) decided by whether it is logically possible for the person(s) who have the correlative duty to meet the demands of the right. Hence, even if (v) is true, it is irrelevant to whether future persons have rights against present persons. What matters is whether it is possible to satisfy the rights of future persons at the time at which the correlative duty is had, namely the present. At the present time, it certainly is logically possible to provide future generations with at least some things to which they may have rights, for example, clean water, clean air, and certain natural resources. ${ }^{19}$ The sense in which 
this is possible is that the future is open; it is open to the present generation to preserve certain natural resources and conditions for life for future generations.

This eternalist response is effective against De George's claim that the resources future persons are said to have a right to are not available to them. The eternalist can agree that no one, including future persons, can have a right to what is not available in the sense of not EXISTING, that is, not existing at any time. But she does not think that the resources under consideration are unavailable to future persons in this sense. She holds that these resources EXIST, though at an earlier time than future persons do. They are available to future persons insofar as the present generation-those who have a duty to future generations-can do something to help secure those resources for future generations.

The response also shows why Beckerman and Pasek's $(2001,17)$ analogy between the rights of future persons to resources and Tommy's right to his toy breaks down. Let us grant that Tommy does not have a right to his original toy. Once Billy destroys the toy, it is not possible for Tommy's putative right to the toy to be satisfied; it is impossible for Billy to do anything to satisfy this putative right, hence Tommy has no such right. Unlike Tommy and Billy, however, future persons and present persons are not contemporaries. The duties that present persons are said to have to future persons are had at a time when those resources exist, that is, at a time when it is possible for them to be preserved for later generations. So unlike Billy, it is possible for present persons to satisfy the rights with which they are thought to have correlative duties.

Eternalists, we said, emphasize the similarity between space and time. The following analogy can help make sense of the eternalist response to the nosatisfaction argument. Suppose you are 100 miles from home. You have a right to your home and to the possessions contained therein. Your possessions are not available to you to make use of at your spatial location, since they are 100 miles away from you. But that makes no difference to your right to them, nor to the correlative duty I have not to burn down your house and everything inside. I can help provide you with the possessions you have a right to by not destroying them. Like spatial remoteness, temporal remoteness does not preclude persons from having rights to things at different times than the times at which they exist. Just as I can help secure your rights at a spatial distance, so too can the present generation help provide future generations with the resources to which they have a right at a temporal distance. The eternalist should, therefore, be in full support of Ernest Partridge when he says, "Time does not diminish the prima facie force of duty, although it may be conjoined with a diminished certainty or efficacy of one's attempt to fulfill that duty. In such cases the factors of probability, efficacy, and deliberative choice, as such, not time, are morally relevant" $(1990,48)$.

\section{Conclusion}

Above I addressed two central arguments against attributing rights to future persons. I argued that adopting an eternalist ontology provides a framework in 
which to successfully respond to the arguments. Key to the eternalist response to these arguments is the commitment to the tenseless EXISTENCE of future persons, who may be bearers of rights at the times at which they exist. I want to conclude by briefly considering some of the ramifications for our thinking about intergenerational ethics if eternalism is the correct ontology of time and there EXIST future persons/generations.

First, it would provide an underappreciated source of support for rights-based and, more generally, individualistic approaches to intergenerational ethics, for example, those that make use of person-affecting conceptions of harm. ${ }^{20}$ Even those on which our obligations are directed at future communities or generations rather than future individuals find support from eternalism. ${ }^{21}$ What eternalism offers is an ontology in which cross-temporal normative relations are intelligible. This would help explain how we could have obligations to or obligations directed at future persons/generations. ${ }^{22}$ For if future persons/generations actually EXIST, then they are, other things being equal, eligible to be among the relata of normative relations, for example, having a duty to $A$ (or not-A) toward $X$ and having a right to $A$ (or not-A) against $X$, that hold across times. The truth of eternalism would, moreover, help explain the possibility of those obligations in terms of the actual interests of those particular persons/generations rather than purely general and impersonal moral principles. $^{23}$

Second, if eternalism is true and there are persons/generations EXISTING at times later than this one, then it is a determinate fact about our world that there ARE persons/generations at times later than this one who HAVE interests, rights, and may be harmed. Such persons/generations are not merely possible, nonexistent, indeterminate, or unactualized. Even if we are ignorant of their identity and number, they are as real and determinate as we are. And insofar as present persons can act in such a way that the interests and rights of such persons are affected, present persons would seem to incur obligations to those particular future persons/ generations. Prima facie, this would challenge any view that alters or weakens our future directed obligations on the basis of the (allegedly) diminished ontological status of the future, ${ }^{24}$ because such views would be (explicitly or implicitly) drawing on noneternalist conceptions of the future for their plausibility.

Obviously, more would need to be said to defend or rebut the views mentioned here. Nevertheless, what the foregoing shows is that our ontological commitments regarding time ought to be factored into our theorizing about our obligations to the future. For if the arguments of this paper are correct, then eternalism offers proponents of intergenerational rights an ontological framework that can be used to undermine key arguments against their position.

I would like to thank two anonymous reviewers from the journal, Christopher Tucker, Chad Vance, and Joshua Gert for helpful comments on earlier versions of the paper. I' $m$ also grateful for conversations regarding the paper I had with Jonah P. B. Goldwater, Wesley Cray, Kate Richie, and audiences at the Ohio State University and the 2016 Alabama Philosophical Society meeting. 


\section{Financial support was generously provided by a Faculty Summer Research Grant from the College of William \& Mary.}

\section{Notes}

${ }^{1}$ I assume that to have a right is to have a valid claim to something and against someone. Having a right entails someone's having a correlative duty or obligation to satisfy the right. But while every right entails a duty, not every duty entails that someone possesses a correlative right (cf. H. L. A. Hart 1955; Joel Feinberg 1970; John Rawls 1972, 108ff.). Annette Baier (1981), Avner de Shalit (1995), Robert Elliot (1989), Joel Feinberg (1974), Ori J. Herstein (2009), Norbert Hoerster (1991), Ruth Macklin (1981), Lukas Meyer (2016), Ernest Partridge (1990), Galen K. Pletcher (1981), Bruce Reichenbach (1992), Eugene Schlossberger (2008), and James Sterba (1980) all hold that future persons may be attributed rights against the present generation.

${ }^{2}$ I should note that W. V. O. Quine (1987, 74-5) seems to have been the first to connect eternalism with the question of our obligations to future persons. The argument of this paper is in line with his brief remarks on the matter.

${ }^{3}$ See Robin LePoidevin (1991), David Lewis (1986), D. H. Mellor (1981, 1998), Hermann Minkowski ([1908] 1923), Nathan Oaklander (2004), Daniel Peterson and Michael Silberstein (2010), Hilary Putnam (1967), W. V. O. Quine (1960, 1987), Theodore Sider (2001), J. J. C. Smart (1949), Robert Weingard (1972), and Donald Williams (1951) for defenses of eternalism.

${ }^{4}$ John Bigelow (1996), Craig Bourne (2006), Thomas Crisp (2003), M. Oreste Fiocco (2007), Mark Hinchliff (2000), Ned Markosian (2002, 2004), Trenton Merricks (1994, 1995, 1999), Arthur N. Prior $(1959,1967)$, and Dean Zimmerman $(1996,2005,2008)$ defend presentism.

${ }^{5}$ C. D. Broad (1923), Peter Forrest $(2004,2006)$, and Michael Tooley (1997) defend the growing block view.

${ }^{6}$ See, for example, Sider (2001), Michael C. Rea (2003), Lawrence Sklar (1985), Ferrell Christensen (1981), and Putnam (1967).

${ }^{7}$ See Kristie Miller (2013), Ned Markosian (2004), and Ned Markosian, Meghan Sullivan, and Nina Emery (2014) for overviews of the debates.

${ }^{8}$ Hence, I would not be arguing here that presentists and growing block theorists cannot account for the rights of future persons. However, I have argued elsewhere (see Griffith n.d.) that the various attempts to attribute rights to nonexistent future persons are unconvincing, for example, those of de Shalit (1995), Elliot (1989), Herstein (2009), Hoerster (1991), Meyer (2016), Partridge (1990), Pletcher (1981), Reichenbach (1992), Schlossberger (2008), and Sterba (1980). In a nutshell, I consider the challenge of attributing rights to nonexistent future persons to be a particularly intractable case of the general problem that "cross-temporal" relations pose to those who deny the existence of nonpresent objects. Rea (2003), Matthew Davidson (2003), and Giuliano Torrengo (2006, 2010) pose the problem of cross-temporal relations for presentists. See M. Oreste Fiocco (2007), Markosian (2004), Crisp (2005), and Rafael De Clercq (2006) for presentist defenses.

${ }^{9}$ See M. A. Roberts (2015) for an overview of the nonidentity problem and putative solutions. See James Woodward (1986), Doran Smolkin (1999), Rahul Kumar (2003), and David J. Velleman (2008) who offer rights-based approaches to the nonidentity problem. As far as I know, no one has approached the nonidentity problem from the perspective of the different ontologies of time.

${ }^{10}$ Beckerman and Pasek $(2001,16)$ and Macklin $(1981,151)$ make this claim.

${ }^{11}$ Hillel Steiner $(1983,159)$ and Herstein $(2009,1181)$ offer similar arguments.

${ }^{12}$ Macklin's argument does not trade on this assumption, only on the assumption only actual persons can have rights against actual persons.

${ }^{13}$ In fairness to Earl, he admits that if eternalism is true, then the paradox can be resolved by denying (II) $(2011,64)$, which is consistent with the thesis of this paper. At any rate, Earl's discussion suggests that an important factor in determining the way out of the (alleged) paradox is what ontology of time is correct. 
${ }^{14}$ Beckerman and Pasek (2001, 16), De George (1981), and Parfit $(1987,356)$ endorse this condition.

${ }^{15}$ However, see Walter Sinnott-Amstrong (1984), Schlossberger (2008), and Moti Mizrahi (2009), among others, who deny that ought implies can.

${ }^{16}$ See Partridge $(1990,62)$ and Douglas MacLean $(1983,5)$.

${ }^{17}$ Which is not to say that the state of the world at $t_{2}$ (or the world considered atemporally) is unsettled or indeterminate. See Elizabeth Barnes and Ross Cameron (2009, 293, 305ff.; 2011) for this conception of the open future.

${ }^{18}$ Even some who think that the rights of future persons can exist without bearers hold that such rights are "contingent upon" the future existence and interests of those persons. See, for example, Elliot (1989, 161), de Shalit (1995, chap. 5), and Reichenbach (1992, 214).

${ }^{19}$ Cf. Elliot $(1989,167)$ and Partridge $(1990,54)$.

${ }^{20}$ Such a conception says, roughly, an act is wrong only if that act harms an actual person (present or future). See Molly Gardner (2016) who defends a related principle partly by appeal to eternalism.

${ }^{21}$ Herstein (2009) thinks we have obligations to future generations but not future individuals. Communitarian approaches intergenerational ethics would be included here.

${ }^{22}$ See Earl $(2011,71)$ and Pletcher $(1981)$ on directed and nondirected obligations.

${ }^{23}$ Certain forms of utilitarianism and virtue ethics make use of such principles. See Parfit (1987, 378ff.), Peter Singer (2011, 107ff.), and Temkin (1993, 221ff.) for discussions of impersonal conceptions of harm in relation to the nonidentity problem.

${ }^{24}$ For example, Beckerman and Pasek (2001), De George (1981), Earl (2011), Macklin (1981), and Steiner (1983). It would also challenge views that seek to explain our future-oriented duties in exclusively impersonal terms.

\section{References}

Adams, Robert Merrihew. 1979. "Existence, Self-Interest, and the Problem of Evil.” Nous 13: 5365.

Baier, Annette. 1981. "The Rights of Past and Future Persons.” In Responsibilities to Future Generations: Environmental Ethics, ed. Ernest Partridge, 171-83. New York: Prometheus Books.

Barnes, Elizabeth, and Ross Cameron. 2009. "The Open Future: Bivalence, Determinism, and Ontology." Philosophical Studies 146: 291-309.

Barnes, Elizabeth, and Cameron, Ross. 2011. "Back to the Open Future." Philosophical Perspectives 25: $1-26$.

Beckerman, Wilfred, and Pasek, Joanna. 2001. Justice, Posterity, and the Environment. Oxford: Oxford University Press.

Bigelow, John. 1996, "Presentism and Properties." In Philosophical Perspectives, Volume 10: Metaphysics, ed. James Tomberlin, 35-52. Oxford: Blackwell.

Bourne, Craig. 2006. A Future for Presentism. Oxford: Oxford University Press.

Broad, C. D. 1923. Scientific Thought. London: Routledge and Kegan Paul.

Christensen, Ferrell. 1981. "Special Relativity and Space-Like Time." British Journal for the Philosophy of Science 32: 37-53.

Crisp, Thomas. 2003. "Presentism." In The Oxford Handbook of Metaphysics, ed. Dean Zimmerman and Michael J. Loux, 211-45. Oxford: Oxford University Press.

—. 2005. "Presentism and 'Cross-Time' Relations." American Philosophical Quarterly 42: 5-17.

Davidson, Matthew. 2003. "Presentism and the Non-Present." Philosophical Studies 113: 77-92.

De Clercq, Rafael. 2006. "Presentism and the Problem of Cross-Temporal Relations." Philosophy and Phenomenological Research 72: 386-402.

De George, Richard. 1981. "The Environment, Rights, and Future Generations." In Responsibilities to Future Generations: Environmental Ethics, ed. Ernest Partridge, 157-66. New York: Prometheus Books.

de Shalit, Avner. 1995. Why Posterity Matters: Environmental Policies and Future Generations. New York: Routledge. 
Earl, Dennis. 2011. “Ontology and the Paradox of Future Generations.” Public Reason 3: 60-72. Elliot, Robert. 1989. “The Rights of Future Persons.” Journal of Applied Philosophy 6: 159-69. Feinberg, Joel. 1970. “The Nature and Value of Rights.” Journal of Value Inquiry 4: 603-14.

—. 1974. "The Rights of Animals and Unborn Generations." In Philosophy and Environmental Crisis, ed. William T. Blackstone (Athens: University of Georgia Press), 43-68.

Fiocco, M. Oreste. 2007. "A Defense of Transient Presentism." American Philosophical Quarterly 44: 191-212.

2013. "Consequentialism and the World in Time." Ratio 26: 212-24.

Forrest, Peter. 2004. "The Real but Dead Past: A Reply to Braddon-Mitchell.” Analysis 64: 358-62. 2006. "Uniform Grounding of Truth and the Growing Block Theory: A Reply to Heathwood." Analysis 66: 161-163.

Gardner, Molly. 2016. "Beneficence and Procreation.” Philosophical Studies 173: 321-36.

Griffith, Aaron M. N.d. "Intergenerational Rights and the Problem of Cross-Temporal Normative Relations.” Unpublished manuscript.

Hart, H. L. A. 1955. "Are There Any Natural Rights?” The Philosophical Review 64: 175-91.

Herstein, Ori J. 2009. "The Identity and (Legal) Rights of Future Generations." The George Washington Law Review 777: 1173-215.

Hinchliff, Mark. 2000. "A Defense of Presentism in a Relativistic Setting." Philosophy of Science 67: S575-86.

Hoerster, Norbert. 1991. Abtreibung Im Säkularen Staat. Frankfurt, Germany: Suhrkamp.

Kavka, Gregory. 1981. “The Paradox of Future Individuals.” Philosophy and Public Affairs 11: 93-112.

Kumar, Rahul. 2003. "Who Can Be Wronged?” Philosophy and Public Affairs 31: 98-118.

LePoidevin, Robin. 1991. Change, Cause, and Contradiction. New York: St. Martin's Press.

Lewis, David. 1986, On the Plurality of Worlds, Oxford: Basil Blackwell.

Macklin, Ruth. 1981. "Can Future Generations Correctly Be Said to Have Rights?” In Responsibilities to Future Generations: Environmental Ethics, ed. Ernest Partridge, 151-56. New York: Prometheus Books.

MacLean, Douglas. 1983. "A Moral Requirement for Energy Policies." In Energy and the Future, ed. Douglas MacLean and Peter Brown, 180-96. Totowa, NJ: Rowman and Littlefield.

Markosian, Ned. 2002. "The Truth About the Past and the Future," in Around the Tree: Semantic and Metaphysical Issues concerning Branching Time and the Open Future, ed. Fabrice Correia and Andrea Iacona, 127-41. Dordrecht, The Netherlands: Springer.

- 2004. "A Defense of Presentism." Oxford Studies in Metaphysics 1: 47-82.

Markosian, Ned, Meghan Sullivan, and Nina Emery. 2014. "Time." In The Stanford Encyclopedia of Philosophy, Fall 2016 Edition, ed. Edward N. Zalta. Retrieved January 20, 2017, from http://plato.stanford.edu/archives/spr2014/entries/time/.

Mellor, D. H. 1981. Real Time. Cambridge: Cambridge University Press.

Mellor, Dh. 1998. Real Time II. London: Routledge.

Merricks, Trenton. 1999. "Persistence, Parts, and Presentism." Nô̂s 33: 421-38.

- 1995. "On the Incompatibility of Enduring and Perduring Entities." Mind 104: 523-31. 1994. "Endurance and Indiscernibility." Journal of Philosophy 91: 165-84.

Meyer, Lukas. 2016. "Intergenerational Justice." In The Stanford Encyclopedia of Philosophy, Summer 2016 Edition, ed. Edward N. Zalta. Retrieved January 20, 2017, from http://plato.stanford.edu/archives/sum2016/entries/justice-intergenerational/.

Miller, Kristie. 2013. "Presentism, Eternalism, and the Growing Block." In A Companion to the Philosophy of Time, ed. Heather Dyke and Adrian Bardon, 345-64. Oxford: Wiley-Blackwell.

Minkowski, Hermann. [1908] 1923. "Space and Time." In The Principle of Relativity: A Collection of Original Memoirs on the Special and General Theory of Relativity, by H. A. Lorentz, A. Einstein, H. Minkowski, and H. Weyl, 73-91. London: Methuen.

Mizrahi, Moti. 2009. “'Ought' Does Not Imply 'Can'.” Philosophical Frontiers 4: 19-35.

Oaklander, Nathan. 2004. The Ontology of Time. New York: Prometheus Books.

Parfit, Derek. 1987. Reasons and Persons. Oxford: Clarendon Press. 
Partridge, Ernest. 1990. "On the Rights of Future People." In Upstream/Downstream: Issues in Environmental Ethics, ed. Donald Scherer, 40-66. Philadelphia: Temple University Press.

Peterson, Daniel, and Michael Silberstein. 2010. "Relativity of Simultaneity and Eternalism: In Defense of the Block Universe." In Space, Time and Space-Time: Fundamental Theories of Physics, ed. Vesselin Petko, vol. 167, part 2, 209-37. Berlin: Springer.

Pletcher, Galen K. 1981. "The Rights of Future Generations." In Responsibilities to Future Generations: Environmental Ethics, ed. Ernest Partridge, 167-70. New York: Prometheus Books.

Prior, Arthur N. 1959. "Thank Goodness That's Over." Philosophy 34: 12-7. 1967. Past, Present, and Future. Oxford: Oxford University Press.

Putnam, Hilary. 1967. "Time and Physical Geometry." Journal of Philosophy 64: 240-47.

Quine, W. V. O. 1960. Word and Object. Cambridge, MA: MIT Press.

—. 1987. Quiddities. Boston: Harvard University Press.

Rawls, John. 1972. A Theory of Justice. Oxford: Oxford University Press.

Rea, Michael C. 2003. "Four-Dimensionalism." In The Oxford Handbook of Metaphysics, ed. Michael J. Loux and Dean W. Zimmerman, 246-80. Oxford: Oxford University Press.

Reichenbach, Bruce. 1992. "On Obligations to Future Generations." Public Affairs Quarterly 6: $207-25$.

Roberts, M. A. 2015. "The Nonidentity Problem." In The Stanford Encyclopedia of Philosophy, Winter 2015 Edition, ed. Edward N. Zalta. Retrieved January 20, 2017, from http://plato.stanford. edu/archives/win2015/entries/nonidentity-problem/.

Schlossberger, Eugene. 2008. A Holistic Approach to Rights. Lanham, MD: University Press of America.

Schwartz, Thomas. 1978. "Obligations to Posterity." In Obligations to Future Generations, ed. R. I. Sikora and Brian Barry, 3-14. Philadelphia: Temple University Press.

Sider, Theodore. 2001. Four-Dimensionalism. Oxford: Clarendon Press.

Singer, Peter. 2011. Practical Ethics, 3rd ed. Cambridge: Cambridge University Press.

Sinnott-Amstrong, Walter. 1984. “'Ought' Conversationally Implies 'Can'.” Philosophical Review 93: 249-61.

Sklar, Lawrence. 1985. "Time, Reality, and Relativity." In Lawrence Sklar, Philosophy and Spacetime Physics. Berkeley: University of California Press.

Smart, J. J. C. 1949. “The River of Time.” Mind 58: 483-94.

Smolkin, Doran. 1999. "Toward a Rights-Based Solution to the Non-Identity Problem." Journal of Social Philosophy 30: 195-6.

Sterba, James. 1980. "Abortion, Distant Peoples, and Future Generations." Journal of Philosophy 77: 424-40.

Steiner, Hillel. 1983. "The Rights of Future Generations." In Energy and the Future, ed. Douglas MacLean and Peter G. Brown, 151-65. Totowa, NJ: Rowman and Littlefield.

Temkin, Larry. 1993. Inequality. Oxford: Oxford University Press.

Tooley, Michael. 1997. Time, Tense, and Causation. Oxford: Oxford University Press.

Torrengo, Giuliano. 2006. "Cross-Temporal Tenseless Relations." Metaphysica 7: 117-29.

- 2010. "Time, Context, and Cross-Temporal Claims." Philosophia 38: 281-96.

Velleman, David James. 2008. "Persons in Prospect." Philosophy and Public Affairs 36: 221-88.

Weingard, Robert. 1972. "Relativity and the Reality of Past and Future Events." British Journal for the Philosophy of Science 23: 119-21.

Williams, Donald. 1951. "The Myth of Passage." Journal of Philosophy 48: 457-72.

Woodward, James. 1986. “The Non-Identity Problem.” Ethics 96: 804-31.

Zimmerman, Dean W. 1996. "Persistence and Presentism." Philosophical Papers 25: 115-26.

Zimmerman, Dean. 2005. "The A-theory of Time, the B-theory of Time, and 'Taking Tense Seriously." Dialectica 59: 401-57.

—. 2008. "The Privileged Present: Defending an 'A-Theory' of Time." In Contemporary Debates in Metaphysics, ed. Theodore Sider, John Hawthorne, and Dean W. Zimmerman, 211-26. Oxford: Blackwell. 